\title{
The significance of organic carbon and nutrient export from peatland-dominated landscapes subject to disturbance, a stoichiometric perspective
}

\author{
S. Waldron ${ }^{1}$, H. Flowers ${ }^{2}$, C. Arlaud ${ }^{3}$, C. Bryant ${ }^{4}$, and S. McFarlane ${ }^{2}$ \\ ${ }^{1}$ Department of Geographical and Earth Sciences, University of Glasgow, Glasgow G12 8QQ, UK \\ ${ }^{2}$ Department of Chemistry, University of Glasgow, Glasgow G12 8QQ, UK \\ ${ }^{3}$ Ecole Nationale Superieure Agronomique de Toulouse, 31326 Castanet-Tolosan, France \\ ${ }^{4}$ NERC Radiocarbon Lab, Scottish Enterprise Technology Park, East Kilbride G75 0QF, UK
}

Received: 31 January 2008 - Published in Biogeosciences Discuss.: 10 March 2008

Revised: 27 January 2009 - Accepted: 27 January 2009 - Published: 13 March 2009

\begin{abstract}
The terrestrial-aquatic interface is a crucial environment in which to consider the fate of exported terrestrial carbon in the aquatic system. Here the fate of dissolved organic carbon (DOC) may be controlled by nutrient availability. However, peat-dominated headwater catchments are normally of low nutrient status and thus there is little data on how DOC and nutrient export co-varies. We present nutrient and DOC data for two UK catchments dominated by peat headwaters. One, Whitelee, is undergoing development for Europe's largest windfarm. Glen Dye by comparison is relatively undisturbed. At both sites there are significant linear relationships between DOC and soluble reactive phosphorus and nitrate concentrations in the drainage waters. However, inter-catchment differences exist. Changes in the pattern of nutrient and carbon export at Whitelee reveal that landscape disturbance associated with windfarm development impacts the receiving waters, and that nutrient export does not increase in a stoichiometric manner that will promote increase in microbial biomass but rather supports aquatic respiration. In turn greater $\mathrm{CO}_{2}$ efflux may prevail. Hence disturbance of terrestrial carbon stores may impact the both the aquatic and gaseous carbon cycle. We suggest estimates of aquatic carbon export should inform the decision-making process prior to development in ecosystems and catchments with high terrestrial carbon storage.
\end{abstract}

Correspondence to: S. Waldron (Susan.Waldron@ges.gla.ac.uk)

\section{Introduction}

Lower-order drainage systems at the terrestrial-aquatic interface represent the first aquatic environment in which terrestrially-exported carbon can be recycled and are particularly interesting as they tend to be more hydrologically responsive and less-well buffered chemically than larger systems. Increasing freshwater dissolved organic carbon (DOC) export has been observed by many (Roulet and Moore, 2006), the cause of which has been debated (e.g., Evans et al., 2002), but globally is strongly correlated with a decrease in atmospheric acid deposition (Monteith et al., 2007).

Freshwater bodies connect terrestrial $\mathrm{C}$ losses with the atmospheric carbon cycle through degassing of soil-derived $\mathrm{CO}_{2}$ in headwaters (e.g., Hope et al., 2004), and $\mathrm{CO}_{2}$ production from heterotrophic respiration (e.g., Lennon, 2004) and uv-oxidation (e.g., Osburn et al., 2001) of exported DOC, resulting in $\mathrm{CO}_{2(\mathrm{aq})}$ over-saturation and efflux (Cole et al., 2007). Catchment drainage systems are thus important sources of atmospheric $\mathrm{CO}_{2}$ (Cole et al., 2007) and greater [DOC] can fuel higher $\mathrm{CO}_{2}$ efflux. For example, respiration from freshwater microbial communities over a 3 to $16.8 \mathrm{mg} \mathrm{C} / \mathrm{L}$ DOC gradient increased linearly with increased [DOC] regardless of differences in the source (and thus inferred quality) of the DOM (Lennon and Pfaff, 2005). Contemporaneous nutrient availability will influence the connection of terrestrial and atmospheric $\mathrm{C}$ cycle: ecological stoichiometric theory predicts that the potential for DOC to be respired to $\mathrm{CO}_{2}$ is strongly influenced by availability of $\mathrm{P}$ and $\mathrm{N}$. The latter are requisite for biomass production; without such nutrients, maintenance respiration is more likely.

Published by Copernicus Publications on behalf of the European Geosciences Union. 
This is a simplistic summary as the interaction of carbon and nutrient in surface waters is more complex - for example, bacterial production is additionally influenced by community structure and environmental conditions, such as temperature (Lennon and Pfaff, 2005) - but ultimately nutrient availability will influence the fate of exported carbon. Few studies of DOC export have considered contemporaneous nutrient availability, yet assessing this in drainage systems may reveal why a system is net heterotrophic or autotrophic, a trophic classification for lotic systems recently proposed necessary (Dodds, 2006). Our first aim is to assess if relationships exist between DOC and nutrient export from two contrasting Scottish field sites draining soils rich in carbon: Whitelee, a partially-forested peat and peaty podzol ridge, now undergoing development to host Europe's largest on-shore windfarm (status at planning approval in summer 2006); for comparison, Glen Dye, a peaty-podzol dominated moorland with no trees, and comparatively little landscape management.

At Whitelee, the peatland is in the catchment headwaters and thus can be distant from sampling locations; Glen Dye sampling points are more intimately placed in the peatland and peaty podzols and attenuation of headwater imports should be less. The hydrological control is important and thus we hypothesise that if the catchment $\mathrm{C}$ and nutrient loads are derived from the same source, or share similar export pathways, then the concentrations should be positively correlated; if they are derived from different source or share different export pathways, such positive correlation will not exist.

Soil disturbance and extensive deforestation are required for the windfarm construction. Despite best practice (Forestry Commission, 1993), clear-felling of forest and the peat disturbance, compaction and dewatering arising from turbine and road construction can impact run-off and nutrient dynamics. Timber-felling on peaty-mineral soils generally leads to an increase in streamwater [DOC] which may persist for a few years, especially at a local scale (e.g., Neal, 2004; Neal et al., 2004a, b); when clear-felled (vs. phased-felling), nitrate concentrations in run-off can be higher for several years after deforestation (Neal et al., 2004a); increases in phosphorus (P) appear more localised (Neal, 2004), except where, as with the some Whitelee catchments, gley (Neal et al., 2004b) or peat soils (Cummins and Farrell, 2003) are present. The inability of peat soils to retain $\mathrm{P}$ has led to significant pollution of streams draining clear-felled peatland soils (Cummins and Farrell, 2003). Whilst immediate and localised impacts can arise from necessary development activities e.g., deforestation (Neal et al., 2004a, b; Kortelainen et al., 2006), how far these impacts propagate to the larger catchment scale is unknown, but important to discern (e.g., Cummins and Farrell, 2003). Thus our second aim is assess whether disturbance of the terrestrial carbon and nutrient stores can be detected in catchment drainage systems outwith the immediate area of disturbance. Additionally, a topographic ridge splits Whitelee into north- and south-draining catchments (hereafter termed N-catchments and S-catchments respectively) with the $\mathrm{N}$-catchments less disturbed than S-catchments. We hypothesise the impact of disturbance should be more apparent in the S-catchments.

Finally, as carbon trading markets grow, carbon sequestered naturally - "carbon landscapes" - will gain importance and the discipline of carbon geomorphology will emerge from cross-disciplinary research to form a coherent subject (Kelly, 2007). Aquatic C loss from undisturbed peatland systems can equal net gaseous atmospheric $\mathrm{C}$ loss (Rivers et al., 1998; Waddington and Roulet, 2000; Billett et al., 2004) and is likely to be exacerbated by activities associated with peatland development. Ultimately, such anthropogenic activity may shift the "delicate" (Rivers et al., 1998) C balance to one of net peatland carbon loss rather than generally gain. We must assess how easily this balance is tipped. Initiatives that allow the sensitivity of a natural carbon store to be assessed have value, particularly for supporting decision-making processes that involve disturbance of these often slow-forming terrestrial $\mathrm{C}$ stores. Thus a third aim of this research is to construct budgets for organic carbon and $\mathrm{P}$ export from Whitelee, providing a case study from which to consider the sensitivity of landscapes, important in carbon sequestration and as source of atmospheric $\mathrm{CO}_{2}$, to disturbance.

\section{Materials and methods}

\subsection{Study sites and sampling strategy}

\subsubsection{Whitelee}

The following description of the Whitelee wind farm has been sourced from the Environmental Impact Statement (EIS) prepared by Scottish Power for planning consent for the windfarm (CRE Energy, 2002). The wind farm will comprise 140 turbines erected over a $176 \mathrm{~km}^{2}$ partially-forested moorland plateau $\left(55^{\circ} 40^{\prime} 24 \mathrm{~N}, 4^{\circ} 16^{\prime} 00 \mathrm{~W}\right)$, in central Scotland (Fig. 1). Land use is predominantly forestry, with rough grazing on open moorland, and more improved pasture and arable land on the northern lower slopes. The windfarm is mostly located in areas of peat, underlain by a clay seal and weakly permeable igneous or moderately permeable sedimentary rocks. Peat depth, measured at 161 locations, ranges from five to over $500 \mathrm{~cm}$, mean depth of $190 \mathrm{~cm}( \pm 1$ S.D. $134.7 \mathrm{~cm})$.

All of the peatlands in the development area are blanket bog, but in some locations have features associated with intermediate bogs. Here the peat is $>4.5 \mathrm{~m}$ deep and there are several large sphagnum-dominated pools and lawns. This contrasts with the surrounding drier, heather-dominated, less species-rich Calluna vulgaris-Eriophorum vaginatum vegetation. 


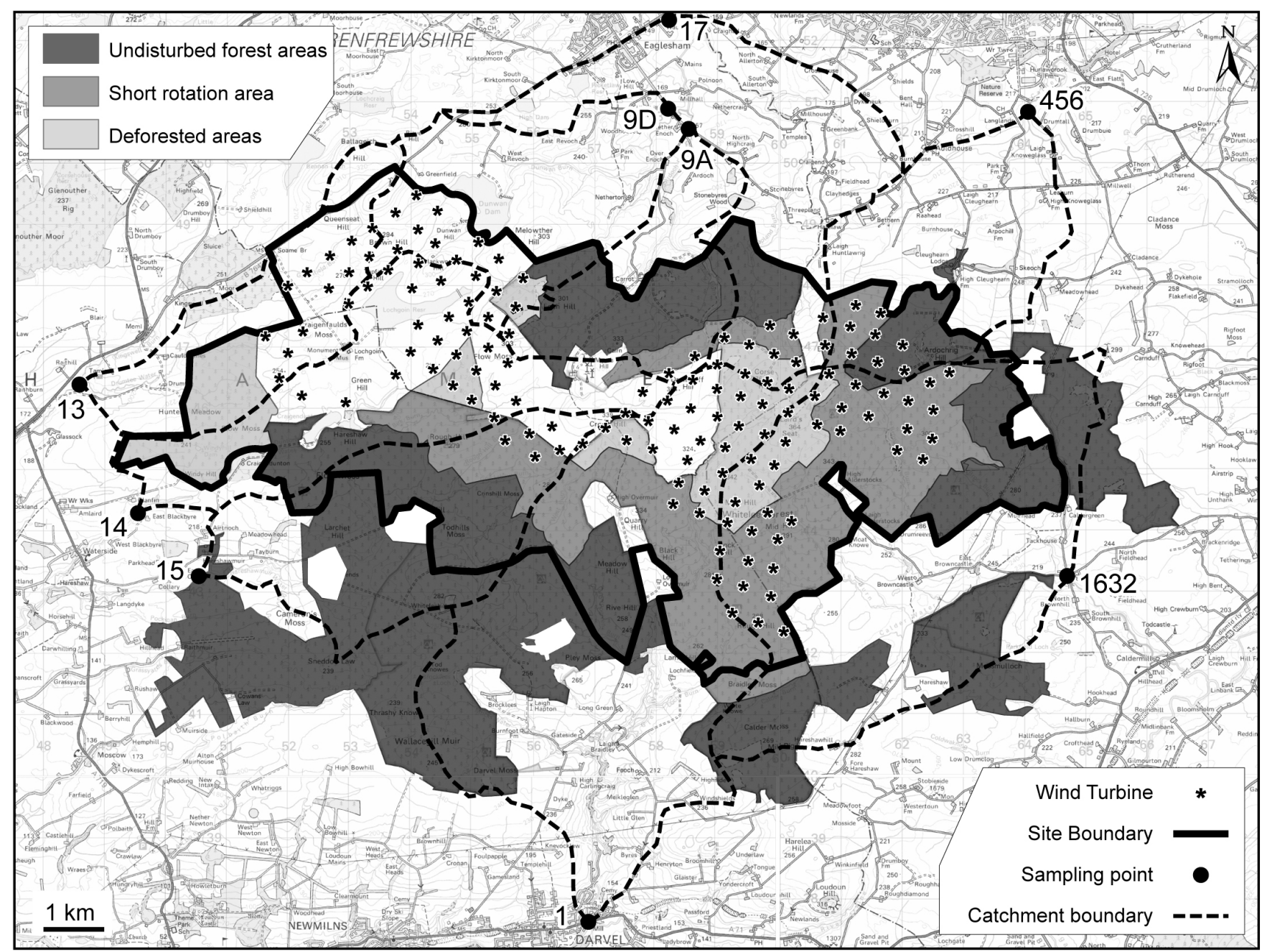

Fig. 1. The Whitelee site showing proposed turbine location, planned deforestation and the nine-subcatchments sampled. The area of each catchment is as follows: WL13: $9.4 \mathrm{~km}^{2}$; WL14: $14.4 \mathrm{~km}^{2}$, WL15: $13.4 \mathrm{~km}^{2}$, WL1: $29.4 \mathrm{~km}^{2} ; \mathrm{WL1632:} 30.0 \mathrm{~km}^{2} ; \mathrm{WL}^{2} 56: 11.7 \mathrm{~km}^{2}$; WL9A: $7.9 \mathrm{~km}^{2}$; WL9D: $11.6 \mathrm{~km}^{2}$; WL17: $34.5 \mathrm{~km}^{2}$.

Only 35 ha $(3.5 \%)$ of the unforested blanket bog is primary natural bog. The remainder has been impacted, mostly due to the Whitelee forest, a first rotation plantation of 5917 ha of mainly Sitka spruce, established between 1962-1992 and at altitude from 220 to $376 \mathrm{~m}$. Within the forest, most of the bog exhibits varying degrees of surface damage and drying. Under canopy closure, bog vegetation has generally been highly modified or lost completely. Outwith the forest and unmodified peatland, acid grassland habitat dominates.

Turbine construction will require excavation of $300000 \mathrm{~m}^{3}$ of peat, road construction (and thus drainage) and felling of 3041 ha of forest. In October 2006 construction of the E-W spine road commenced. Deforestation commenced in winter 2006, but in adherence to Forest and Water guidelines for best practice (Forestry Commission, 1993), is being undertaken as isolated coups. Deforestation required for immediate turbine operation occurred until the end of 2007, with continued management of the forest (to avoid air flow impedence) and non-windfarm related deforestation beyond the end of construction. Quarrying on-site for hardcore created borrow pits in which peat excavated during construction will be stored until later landscaping. The windfarm is proposed to be fully operational in summer 2009.

We commenced sampling of the receiving waters from Whitelee windfarm after planning approval had been announced (May 2006). Figures 3 to 7 include data collected prior to disturbance of surface soils associated with construction. We divided the Whitelee ridge into nine drainage catchments (Fig. 1, catchment sizes given in the legend), with only two catchments nested (WL9D and WL9A are nested in WL17), and four draining north and five draining south. To assess the downstream impact of the development, the catchment sampling points were outwith the site development 
boundaries. All catchments were sampled within five hours, approximately every three weeks. Negligible colonisation by algal communities was observed during sampling trips.

\subsubsection{Glen Dye}

Glen Dye $\left(56^{\circ} 56^{\prime} 27 \mathrm{~N}, 2^{\circ} 36^{\prime} 00 \mathrm{~W}\right)$, a headwater subcatchment of the River Dee in NE Scotland, is predominantly upland in character, with an altitude range from $100-580 \mathrm{~m}$. Detailed diagrams of topography and sampling points, soil coverage, geology and landuse of the Glen Dye catchment are available (Waldron et al., 2007).

The Water of Dye drains a granite-dominated area. The catchment is characterised by extensive plateaux areas on the interfluves above $450 \mathrm{~m}$ that are dominated by peats (up to $5 \mathrm{~m}$ deep) and peaty podzols ( $<1 \mathrm{~m}$ deep). The most freelydraining humus iron podzols $(<1 \mathrm{~m}$ deep) occur only on the more incised catchment slopes and the main river valley bottoms generally have freely draining alluvial deposits and soils. Regular burning of small areas of moorland may have contributed to some peat degradation and hagging (Thompson et al., 2001) and in places erosion extends to the organomineral interface. A high density of ephemeral drainage channels cover the peat, connecting it to the perennial stream channel network.

Data presented are for samples collected from two nested catchment scales within the Water of Dye: at $1.3 \mathrm{~km}^{2}$ from Brocky Burn, a second-order river system draining the hillslope peats and at $41.7 \mathrm{~km}^{2}$ on the Water of Dye. Brocky Burn is a tributary of the Water of Dye (Dawson et al., 2001). The samples were collected approximately monthly from June 2003-August 2004, including event flow (Waldron et al., 2007). The Water of Dye at Charr flume is a 4th-order channel with riffles and pool habitats, circa $10 \mathrm{~m}$ wide. Bracken co-exists with heather and there is little riparian vegetation.

At low flows, sampling site depth is usually less than $50 \mathrm{~cm}$, the water is less coloured, and the particulate load is low ( $3.0 \pm 0.3 \mathrm{mg} / \mathrm{LC}, \mathrm{n}=42$, Waldron, unpublished data). Light penetration supports diatom and algal community growth on bedrock and boulders in the river channel (Waldron et al., 2007).

\subsection{Stoichiometric and isotopic characterisation of [DOC] and $[\mathrm{POC}]$}

The need for stoichiometric characterisation of the DOM pool has been described in the introduction; isotopic analyses have been undertaken to offer insight to the source of $\mathrm{C}$ in the drainage systems.

One litre water samples were collected in polyethylene bottles, and stored cool until freezing (usually within $24 \mathrm{~h}$ ). For analysis (usually within one week), each sample was defrosted, filtered through a pre-combusted GF/F filter $(0.7 \mu \mathrm{m})$, and reduced to a concentrate by rotary evaporation (at $50^{\circ} \mathrm{C}$, and $50 \mathrm{mbar}$ ). Where carbonate was present (con- sidered likely if $\mathrm{pH}$ was greater than 5), the filtrate was acidified to $\mathrm{pH} 4$ with $0.1 \mathrm{M} \mathrm{H}_{2} \mathrm{SO}_{4}$ prior to rotary evaporation. The concentrate was subsequently freeze-dried and $\delta^{13} \mathrm{C}$, wt. $\% \mathrm{C}$ and wt. \% $\mathrm{N}$ assayed by analysis of circa $2 \mathrm{mg}$ of powder on a Costech $\mathrm{C} / \mathrm{N} / \mathrm{S}$ analyser, linked to a ThermoFinnigan continuous flow mass spectrometer. DOC and total dissolved nitrogen concentrations, [DOC] and [TDN], were calculated from the volume of sample filtered, mass of solid residue and wt $\% \mathrm{C}$ and N. [POC] was calculated by assuming $60 \%$ of the loss on ignition (MAFF, 1986) after ashing of oven-dried $\left(105^{\circ} \mathrm{C}\right)$ filter papers at $375^{\circ} \mathrm{C}$ for $16 \mathrm{~h}$ was carbon. Graphite targets (Slota et al., 1987) for ${ }^{14} \mathrm{C}$ analysis at the SUERC AMS Laboratory were prepared by cryogenic separation of $\mathrm{CO}_{2}$ from DOM combusted in sealed quartz tubes (Boutton et al., 1983). ${ }^{14} \mathrm{C}$ results were normalised to $\delta^{13} \mathrm{C}$ of $-25 \%$ o $\left(\delta^{13} \mathrm{C}\right.$ of $\mathrm{CO}_{2}$ subsamples having been measured) and expressed as absolute \% modern (Stuiver and Polach, 1977). Overall analytical precision for $\delta^{13} \mathrm{C}$ and ${ }^{14} \mathrm{C}$ is $0.1 \%$ and $3.5 \%$ respectively.

\subsection{Nutrient analysis}

A second aliquot of samples was stored at $4^{\circ} \mathrm{C}$ until and during analyses. Samples were analysed for soluble reactive phosphorus (SRP) and total phosphorus (TP) concentrations. Additionally from the Whitelee samples only, nitrate and nitrite were characterised. SRP was the priority analyte on return from the field. $\mathrm{N}$ species were measured afterwards (usually the next day). As TP required complete sample digestion and vapour losses are not an issue, this was carried out later (for some samples up to one year after collection). Gaps exist in SRP and nitrate time series due to a number of reasons e.g., samples not analysed within two days were rejected as we were insufficiently confident the measured concentrations were broadly representative of field concentrations.

Samples for TP were digested without filtration. For all other nutrient assays samples were filtered through a $0.2 \mu \mathrm{m}$ Supor membrane filter. All analyses were carried out colorimetrically using a Technicon Autoanalyser II system adapted for low level analysis. SRP was measured using an ammonium molybdate-ascorbic acid method with a limit of quantification of $1 \mu \mathrm{g}$ P/L. TP was digested using a potassium persulphate-sulphuric acid mixture in an autoclave at $121^{\circ} \mathrm{C}$ for $30 \mathrm{~min}$ (Clesceri et al., 1998) prior to analysis by the SRP method.

Total oxidised nitrogen was analysed using a $\mathrm{Cu}-$ Hydrazine reduction method to reduce nitrate to nitrite, subsequently measured by the Griess Ilosvay method. Nitrite was measured directly on a second sample aliquot, using the Griess Ilosvay reaction and nitrate calculated by subtraction. Limits of quantification for nitrate and nitrite were $10 \mu \mathrm{g} \mathrm{N}$ per litre and $1 \mu \mathrm{g} \mathrm{N}$ per litre respectively. Nitrite data is not presented here. 


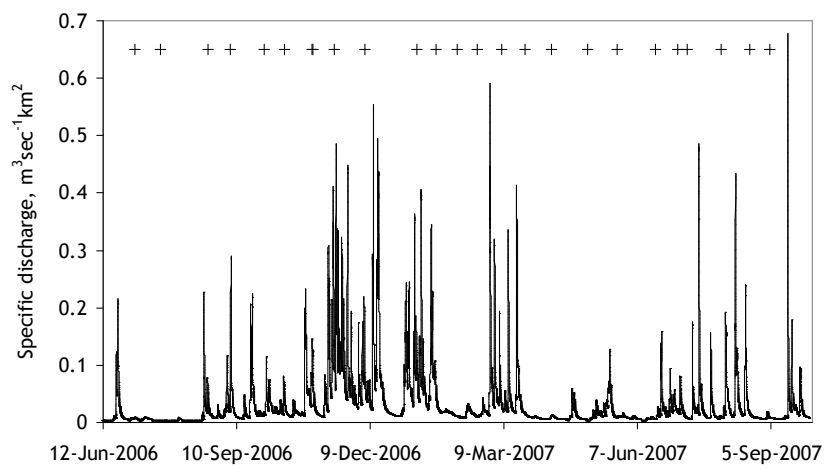

Fig. 2. Specific discharge from the nearest catchment to the Whitelee development currently gauged, the River Irvine at Newmilns, catchment area $72.8 \mathrm{~km}^{2}$. Sampling dates indicated by the crosses.

The significance of nutrients to the fate of exported DOC was not considered at the time of Glen Dye sample collection, and thus for Glen Dye samples, nutrient analyses were carried out on waters of known [DOC] by redissolution of the freeze-dried sample residue in distilled water. The DOM powder aliquots used for nutrient analyses were chosen to span the range of flow conditions (cf. the hydrographic profile in Waldron et al., 2007).

\subsection{Flux estimates and statistical analyses}

The Whitelee catchments are currently ungauged. However, a Scottish Environment Protection Agency gauging station records discharge on the River Irvine at Newmilns (circa $3 \mathrm{~km}$ west of WL1). Whitelee is sufficiently small that the flow regimes of the ungauged catchments are broadly similar to the River Irvine. From this proxy of sub-catchment discharge, it is apparent that sampling was carried out during both base flow and wetter periods (Fig. 2).

From almost bi-monthly time series of nutrient export and the following assumptions we can estimate total fluxes for DOC, POC and TP for each Whitelee catchment:

1. that mean specific discharge (Fig. 2) for the nearest gauging station, scaled for each catchment, describes discharge in each of the study catchments;

2. that the change in the determinant of interest between sampling periods is linear.

Assuming linear change may over-estimate concentration, but this will be somewhat balanced by missing detail of enhanced concentrations occurring with event flow (e.g., Jordan et al., 2007). Further, preliminary spatial survey of WL1632 and WL1 showed either constant [DOC] (at high flow), or a decrease by 5 to $40 \mathrm{mg} \mathrm{C} / \mathrm{L}$ from the head of the catchment to sampling (Ross, 2008). Thus, using the lower catchment outlet concentration to be representative of losses

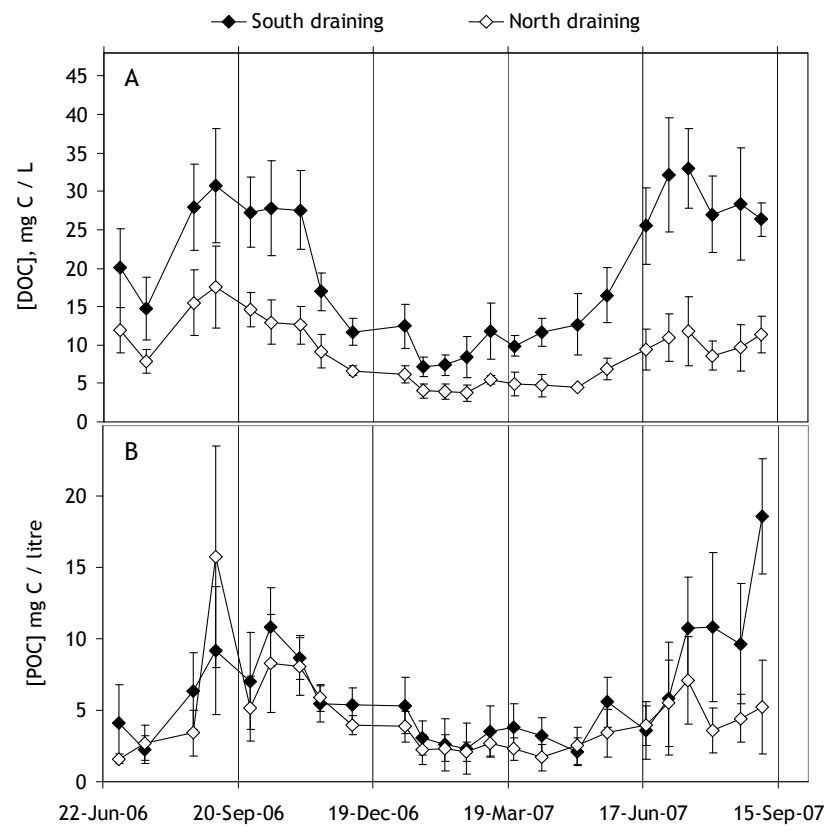

Fig. 3. $[\mathrm{DOC}]$ (panel A) and [POC] (panel B) in Whitelee N- and $\mathrm{S}$-draining catchment waters. Each sample point is the mean $\pm 1 \mathrm{SD}$ of the four $\mathrm{N}$ - or five $\mathrm{S}$-catchments sampled on the same day.

throughout, will generally under-estimate loss. As such, whilst the above assumptions will not always be valid, our approach is conservative and sufficiently robust for preliminary flux estimates.

With the additional following assumptions, estimates of DOC and $\mathrm{P}$ flux allows prediction of maximum $\mathrm{CO}_{2(\mathrm{aq})}$ production for each catchment outflow:

1. all $\mathrm{P}$ is available and all $\mathrm{C}$ in excess of the microbial biomass stoichiometric composition is available for conversion to $\mathrm{CO}_{2}$;

2. the concentrations of both $\mathrm{N}$ and $\mathrm{P}$ are sufficiently high that the system is not nutrient limited.

3. whilst only the N-catchments have excess $\mathrm{N}$, these systems are $\mathrm{P}$ - more than $\mathrm{N}$-limited and thus calculations of excess $\mathrm{C}$ are on the basis of excess C:P.

This estimate is for $\mathrm{CO}_{2}$ production from respired organic matter. There will be a separate contribution to $\mathrm{CO}_{2}(\mathrm{aq})$ from catchment soil dissolved inorganic carbon export (e.g. Waldron et al 2007), not detailed here as not measured.

Statistical analyses were carried using Minitab V 15, based on general linear models, under the assumption of normality, which was tested. 


\section{Results}

Given our hypothesis that S-catchments will be more impacted, we present the data as pooled $\mathrm{N}$ - or S-catchments.

\subsection{DOC and POC data}

Whitelee [DOC] ranges from $3.5 \mathrm{mg}$ C/L (WL9A, 5th February 2007) to $40.1 \mathrm{mg} \mathrm{C/L}$ (WL15, 17 July 07) (Fig. 3a). Brocky [DOC] ranges from 7 to $29.9 \mathrm{mg} \mathrm{C} / \mathrm{L}$ (Fig. 5a) for the samples from which nutrient concentrations are available, although it can be higher than this (unpublished data, Waldron; Dawson et al., 2004). Whilst each sample is a "snapshot" of DOC export and there may be considerable variation between samples depending on hydrological conditions (Grieve, 1994), this seasonal pattern of changing concentrations is observed elsewhere (e.g., Billett et al., 2004; Worrall et al., 2006), with highest concentrations in catchment outflow at the end of summer, after peak terrestrial productivity and strongly influenced by increased hydrological export (Tipping et al., 2007). Early summer 2007 was particularly wet in the UK (Fig. 2) and thus increased [DOC] commences earlier. For all sampling occasions, [DOC] in S-draining Whitelee catchments is greater than the $\mathrm{N}$-catchments.

Whitelee [POC] ranges from $0.41 \mathrm{mg} \mathrm{C} / \mathrm{L}$ (WL15, 19th February 2007) to $23.66 \mathrm{mg}$ C/L (WL15, 4th September 2007) (Fig. 3b). [POC] shows similar seasonality with enhanced export at times of high [DOC] export likely reflecting a hydrological control. Until June 2007, [POC] is comparable in N- and S-catchments. After June 2007, there is separation between $\mathrm{N}$ - and $\mathrm{S}$-catchments, with [POC] higher in the $\mathrm{S}$-catchments than the N-catchments.

\subsection{Nutrient data}

[TP] ranges from $2 \mu \mathrm{gP} / \mathrm{L}$ (WL9D, 23rd March 2007) to $165 \mu \mathrm{g} \mathrm{P} / \mathrm{L}$ (WL17, 5th September 2006) (Fig. 4). Whitelee [TP] shows a similar pattern as [DOC], with higher concentration in the summer months, but offset in [TP] between N- and S-catchments occurs less often. As defined by [TP], the trophic status of the Whitelee drainage waters varies from mesotrophic $(10-\leq 35 \mu \mathrm{g} / \mathrm{L})$, to eutrophic ( $>35-$ $\leq 100 \mu \mathrm{g} / \mathrm{L})$ or hypertrophic $(>100 \mu \mathrm{g} / \mathrm{L})$. [TP] for Brocky samples is generally oligotrophic: 4.0 to $12.7 \mu \mathrm{g} \mathrm{P} / \mathrm{L}$, median [TP] of $7.4 \mu \mathrm{g}$ P/L. However, unlike Whitelee, [TP] has been measured from $0.7 \mu \mathrm{m}$ filtered sample residues. If the relationship between filtered and non-filtered samples observed in Whitelee occurs at Brocky, [TP] may be up to 50\% greater, and trophic status now straddles the oligotrophicmesotrophic boundary.

All field sites display statistically significant relationships between [DOC] and [SRP] (Figure 5A), which are catchment specific, with more SRP exported for a given [DOC] in $\mathrm{N}$-draining Whitelee, than S-draining Whitelee, than Brocky. Statistically significant relationships exists between [DOC]

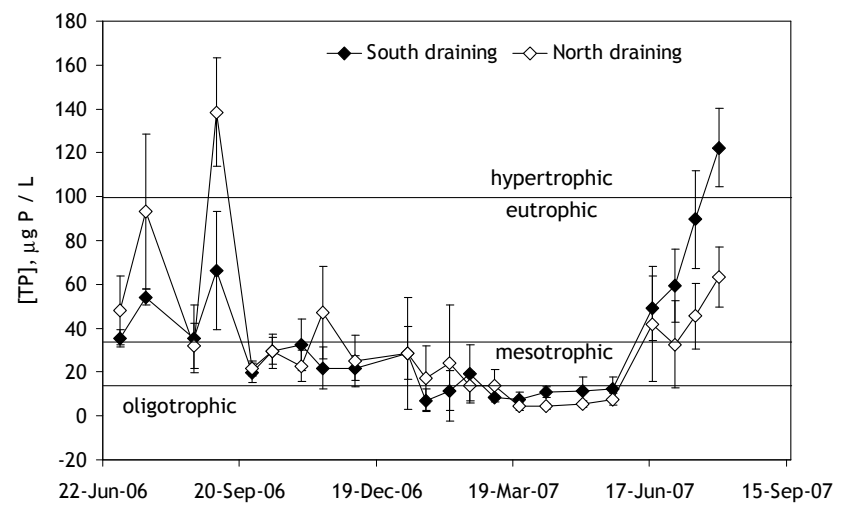

Fig. 4. $[\mathrm{TP}], \mu \mathrm{gP} / \mathrm{L}$, in Whitelee drainage waters. Each sample point is the mean $\pm 1 \mathrm{SD}$ of the four $\mathrm{N}$ - or five $\mathrm{S}$-catchments sampled on the same day.

and [TP] for Whitelee (the difference in sample matrix for Brocky precludes such comparison): Whitelee north: $[\mathrm{TP}]=3.35[\mathrm{DOC}]+3.98, R^{2}=0.219, \mathrm{~F}_{1,82}=24.26, \mathrm{p}<0.0001$; Whitelee south: $[\mathrm{TP}]=1.77[\mathrm{DOC}]-0.03, \quad R^{2}=0.298$, $\mathrm{F}_{1105}=46.03, \mathrm{p}<0.0001$. The lower statistical significance for $[\mathrm{DOC}]-[\mathrm{TP}]$ than $[\mathrm{DOC}]-[\mathrm{SRP}]$ likely reflects a POM contribution in the TP, not present in the DOC.

Whitelee $\left[\mathrm{NO}_{3}^{-}\right]$ranges from $0.1 \mathrm{mg} \mathrm{N} / \mathrm{L}$ (multiple sites on multiple dates) to $1.9 \mathrm{mg} \mathrm{N} / \mathrm{L}$ (WL9A, 5th February 2007) (Fig. 5b). $\left[\mathrm{NO}_{3}^{-}\right]$mostly remains distinct between Whitelee $\mathrm{N}$ - and S-catchments, but the trend is reversed in comparison to $[\mathrm{DOC}]$, with $\left[\mathrm{NO}_{3}^{-}\right]$greater in $\mathrm{N}$ - than $\mathrm{S}$-catchments. The statistically significant relationships between $[\mathrm{DOC}]$ and $\left[\mathrm{NO}_{3}^{-}\right]$show inverse correlation (Fig. $5 \mathrm{~b}$ ). $\left[\mathrm{NO}_{3}^{-}\right]$data does not exist for Brocky.

\subsection{Aquatic stoichiometry}

Whilst nitrate and SRP are immediately available to bacteria without any extracellular processing, when orthophosphate is limiting all osmotrophic organisms can efficiently hydrolyse DOP (Lovdal et al., 2007) and use organic nitrogen as a metabolic source (Lennon and Pfaff, 2005). For these reasons, our stoichiometric ratios are shown as TOC vs. TP and TDN pools, including both biologically available inorganic and organic components. The availability of DOP from humic materials typical of peat export can vary (e.g., He et al., 2006) and C:P estimates reflect maximum $P$ availability.

Figure 6 reveals considerable temporal variability in molar C:P, ranging from 227 (WL9A, 20th February 2007) to 6678 (WL1, 4th April 2007), and molar C:N from 3 (multiple sites, multiple dates) to 50 (WL15, 12th October 2006). Spatial variability between the N- and S-catchments is less marked, although C:P is generally lower in the $\mathrm{S}$ - than $\mathrm{N}-$ catchments. These stoichiometric ratios are similar to values in Finnish catchments also with varying \% peatland (Kortelainen et al, 2006). The seasonal export pattern apparent in 


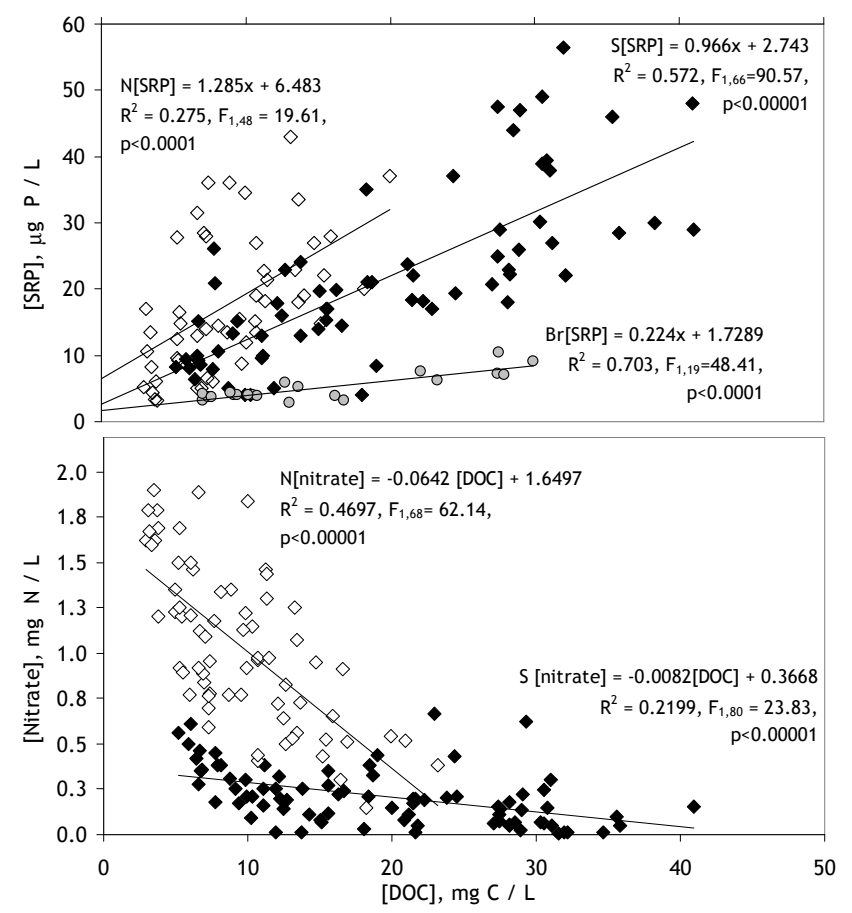

Fig. 5. Interaction between $[\mathrm{DOC}](\mathrm{mg} \mathrm{C} / \mathrm{L})$ and $[\mathrm{SRP}]$ (panel $\mathrm{A}, \mu \mathrm{g} \mathrm{P} / \mathrm{L}$ ) and $\left[\mathrm{NO}_{3}^{-}\right]$(panel $\mathrm{B}, \mathrm{mg} \mathrm{N} / \mathrm{L}$ ). The legend for the Nand S-catchments is the same in Fig. 4; in panel A Brocky samples are represented by the shaded grey circles.

[DOC], and to a lesser extent [TP], is not discernible. Catchment specific differences are maintained with $\mathrm{C}: \mathrm{N}$, with the S-catchments always greatest; both catchments show lowest $\mathrm{C}: \mathrm{N}$ is spring. Both $\mathrm{C}: \mathrm{P}$ and $\mathrm{C}: \mathrm{N}$ are shown relative to microbial biomass stoichiometric composition, which can range from 5-370:1 for C:P and 2.9-7.6:1 for C:N (Cross et al., 2005) but here estimated median value of 59.5:1 for C:P and 5.5:1 for $\mathrm{C}: \mathrm{N}$ have been used. We have chosen a bacterial stoichiometric composition over the Redfield ratio as there was little visible evidence of in-stream primary production. The trend for increasing C:P from June 2006 reverses after May 2007 to compositions that are more similar to microbial stioichiometric requirements. In comparison, there is a sustained difference in C:N between $\mathrm{N}$ - and $\mathrm{S}$-catchments, with $\mathrm{N}$-catchments having compositions comparable to bacterial stoichiometry.

\subsection{Isotopic data}

$\delta^{13} \mathrm{C}_{\text {DOC }}$ shows little intra-site variation (Whitelee: $-29.1 \pm 0.3, \mathrm{n}=208$, Brocky: $-27.7 \pm 0.3 \%$, $\mathrm{n}=21$ ), but inter-site differences exist. The more ${ }^{13} \mathrm{C}$-enriched DOC in Glen Dye drainage water may reflect peat sources of greater humification (Kalbitz and Geyer, 2002), or differences in source $\delta^{13} \mathrm{C}$ e.g., in Whitelee conifer litter may contribute to the DOM pool. However, $\delta^{13} \mathrm{C}_{\mathrm{DOC}}$ from both sites is within

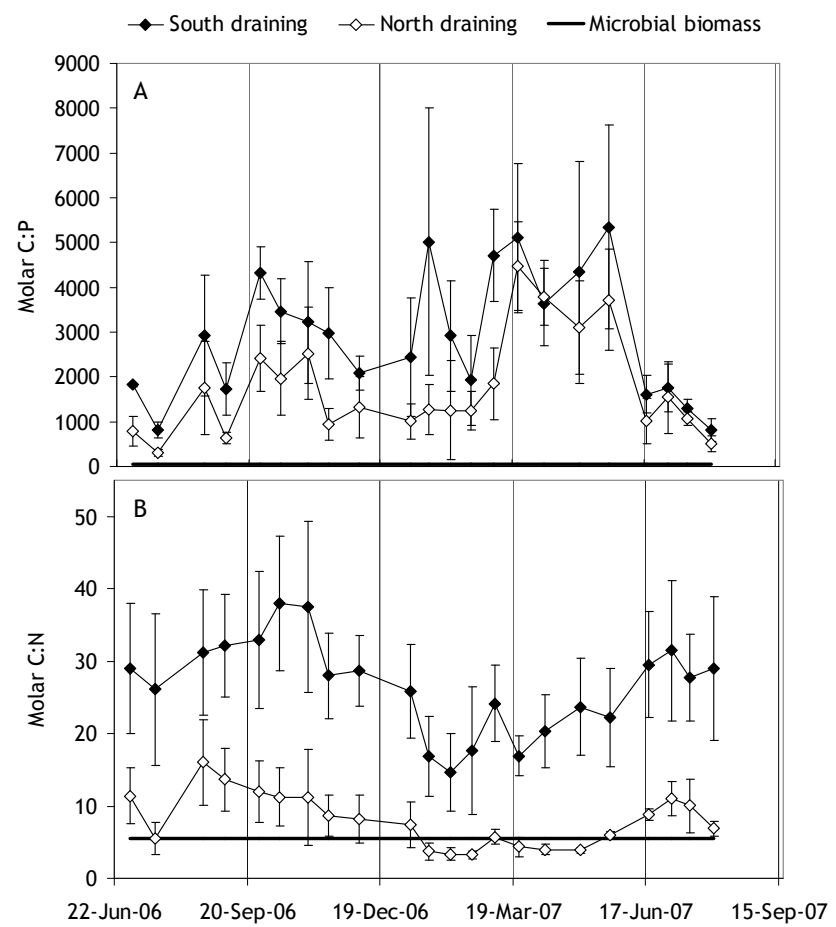

Fig. 6. Molar C:P (panel A) and molar C:N (panel B) for the $\mathrm{N}$ and S-draining Whitelee catchments, relative to microbial biomass (Cross et al., 2005). Each sample point is the mean $\pm 1 \mathrm{SD}$ of the four $\mathrm{N}$ - or five S-catchments sampled on the same day. Molar C:P was calculated from combined DOC and POC, with respect to TP. It was assumed that, as insufficient $P$ is available to meet microbial requirements, particulate $\mathrm{P}$ may be used, and thus particulate $\mathrm{C}$ would also be available. TDN is from the dissolved pool only, thus molar $\mathrm{C}: \mathrm{N}$ was calculated using only DOC.

the range typical of terrestrially-derived carbon, suggesting that the DOC is of dominantly allochthonous origin.

Samples of the Water of Dye, into which Brocky drains circa one $\mathrm{km}$ downstream, taken in 2004 on the falling limb of a hydrological event shows the DOC exported is young (Table 1): ${ }^{14} \mathrm{C}_{\mathrm{DOC}}$ indicates a modern composition, either organic sources deposited circa 1996, or mixing of older carbon with post-1950s carbon, such that by mass balance, the pool signature is modern.

\subsection{Flux estimates}

DOC and POC export range from 6.9-20.6 $\mathrm{g} \mathrm{C} \mathrm{m}^{-2} \mathrm{yr}^{-1}$ and $4.3-6.7 \mathrm{~g} \mathrm{C} \mathrm{m}^{-2} \mathrm{yr}^{-1}$ respectively (total exports are given in Table 2). Summed this loss is similar to smaller peatdominated headwater catchments (cf. Dawson and Smith, 2007). We have no evidence that a significant component of the DOC is autochthonous, thus assuming that Whitelee OC export primarily represents loss from the terrestrial catchment is reasonable. Annual TP flux ranges from 22 to $37 \mathrm{mg} \mathrm{P} \mathrm{m}^{-2} \mathrm{yr}^{-1}$. With the assumption that all DOC in 
Table 1. ${ }^{14} \mathrm{C}_{\mathrm{DOC}}$ from the Water of Charr, the mainstem river into which Brocky Burn discharges, collected during event flow. The average age of the DOC is approximately 8 years (110 absolute \% modern is equivalent to 1996, Levin and Kromer 2004) although the 09:15 a.m. sample is significantly different and indicates carbon with an average age of 11 years.

\begin{tabular}{llll}
\hline Date and time collected & Publ. code & $\begin{array}{l}{ }^{14} \text { C enrichment } \\
\text { (Absolute \% modern) }\end{array}$ & $\delta^{13} \mathrm{C}_{\text {DOC }} \%$ \\
\hline Charr 24/6/04 12:55 & SUERC 7242 & $110.05 \pm 0.34$ & -28.1 \\
Charr 24/6/04 17:30 & SUERC 7243 & $110.25 \pm 0.30$ & -28.2 \\
Charr 24/6/04 22:40 & SUERC 7244 & $110.05 \pm 0.45$ & -28.3 \\
Charr 25/6/04 02:25 & SUERC 7245 & $110.38 \pm 0.34$ & -28.2 \\
Charr 25/6/04 09:15 & SUERC 7246 & $112.57 \pm 0.34$ & -28.3 \\
Charr 25/6/04 12:40 & SUERC 7248 & $111.04 \pm 0.30$ & -28.3 \\
& Mean ( \pm 1 SD) & $110.72 \pm 0.97$ & $-28.2 \pm 0.1$ \\
\hline
\end{tabular}

Table 2. Annual flux estimates of DOC, POC and TP export for one calendar year beginning 3 July 2006. The potential contribution to $\mathrm{CO}_{2(\mathrm{aq})}$ through respiration of DOC and POC in stoichiometric excess of $\mathrm{P}$ consumption can be calculated. *WL17 does not include the nested catchments of 9D and 9A, thus total flux at sampling point 17 is the sum of 9A, 9D and 17.

\begin{tabular}{|c|c|c|c|c|c|c|c|c|c|}
\hline & WL13 & WL14 & WL15 & WL1 & WL1632 & WL456 & WL9A & WL9D & WL17* \\
\hline Area $\left(\mathrm{km}^{2}\right)$ & 9.4 & 14.4 & 13.4 & 29.4 & 30.0 & 11.7 & 7.9 & 11.6 & 15.1 \\
\hline$\Sigma \mathrm{DOC}(\mathrm{Mg})$ & 183 & 246 & 300 & 431 & 541 & 120 & 82 & 86 & 120 \\
\hline$\Sigma \mathrm{POC}(\mathrm{Mg})$ & 51 & 88 & 71 & 213 & 178 & 69 & 43 & 54 & 71 \\
\hline Export $\mathrm{g} \mathrm{C} \mathrm{m}^{-2} \mathrm{yr}^{-1}$ & 23.1 & 21.5 & 25.5 & 20.3 & 22.1 & 14.9 & 14.8 & 11.2 & 11.7 \\
\hline$\Sigma \mathrm{TP}(\mathrm{kg})$ & 257 & 484 & 319 & 1018 & 701 & 453 & 226 & 359 & 597 \\
\hline Export $\mathrm{mg} \mathrm{Pm}^{-2} \mathrm{yr}^{-1}$ & 25.2 & 31.2 & 21.9 & 32.0 & 21.6 & 35.7 & 26.6 & 28.7 & 36.6 \\
\hline Potential $\mathrm{CO}_{2(\mathrm{aq})}(\mathrm{Mg})$ & 177 & 234 & 292 & 408 & 525 & 110 & 77 & 78 & 106 \\
\hline
\end{tabular}

excess of TP can be converted to $\mathrm{CO}_{2}$, maximum $\mathrm{CO}_{2}$ efflux ranges from $6.7-18.9 \mathrm{~g} \mathrm{C} \mathrm{m}^{-2} \mathrm{yr}^{-1}$ across the catchments (Table 2).

\section{Discussion}

Here we focus on Whitelee, with respect to the three aims and associated hypothesis outlined in the introduction, but compare when appropriate, with Brocky, the more pristine peatland.

\subsection{The interaction between DOC and nutrient export}

The statistically significant, $[\mathrm{P}]-[\mathrm{DOC}]$ relationships support our hypothesis that if the $\mathrm{P}$ source is closely linked to the DOC source, and/or they share the same export mechanism they will be positively correlated. The inverse [DOC]-[NO$\left.{ }_{3}^{-}\right]$ linear relationship suggests this is not true for nitrate. In addition to denitrification under anaerobic conditions (not likely in the drainage systems where we have continuously measured high \% DO, but possible in anaerobic soils prior to export to the drainage waters), increased rock outcrop and steeper slope can positively influence nitrate concentrations in stream waters (Smart et al., 2005). These landscape characteristics are not conducive to peat formation, which positively influences [DOC] in drainage waters (e.g., Kortelainen et al., 2006), thus an inverse relationship between nitrate and [DOC] is unsurprising. A limited supply of nitrate diluted by high [DOC] run-off during higher flow, could give rise to negative linear relationships. However, the N-catchments, which have less peat and more farmland than forest, have consistently higher $\left[\mathrm{NO}_{3}^{-}\right]$in drainage waters (Fig. 5b), suggesting this negative relationship reflects catchment specific differences in baseline $\left[\mathrm{NO}_{3}^{-}\right]$rather than dilution of a fixed source.

The linear [DOC]-[P] relationships indicate that DOC and $\mathrm{P}$ export increase together, although inter-catchment differences exist: for a given amount of $\mathrm{C}$, Brocky, the most peat-rich catchment, exports least $\mathrm{P}$, whilst in the Whitelee $\mathrm{N}$-catchments, where there is least peatland, more $\mathrm{P}$ is exported. Observing nutrient-DOC interaction across three different geographic regions suggests similar responses may be found elsewhere. Kortelainen et al. (2006) observed highly significant relationships between TOC and TP and TN (particularly TON) export, but not the inverse relationship with $\mathrm{N}$ found here. 
Although the trophic status of the Whitelee receiving waters is high (Fig. 4), DOC is in excess to microbial requirements (Fig. 6) and thus [DOC] increase may enhance respiration. Temporal variation in the stoichiometry of Whitelee waters may similarly cause temporal variation in $\mathrm{CO}_{2}$ efflux. For example, in the S-catchments increase in [TP] but decrease in [DOC] (reflected by a decrease in molar C:P) since 17th June 2007 may result in lower $\mathrm{CO}_{2}$ efflux. For Whitelee the inferred stoichiometric influence on $\mathrm{CO}_{2}$ efflux suggests larger intra-catchment variation than exists between the pooled $\mathrm{N}$ - and $\mathrm{S}$-catchments.

Understanding why $[\mathrm{DOC}],[\mathrm{P}]$ and $[\mathrm{N}]$ co-vary would be easier if the source of nutrients was known. Aerial deposition can occur, but Whitelee is sufficiently small that this is broadly similar across the catchments, and intra-catchment differences thus indicate run-off is more important in nutrient delivery. Flow pathways from terrestrial reservoirs to drainage waters have complexities of scale, from micropores to peatland piping (e.g., Holden, 2005), thus in catchment-scale studies, pin-pointing the exact source of an allochthonous analyte is challenging. The positive correlations with [DOC] and [P] and the negative correlation with $\left[\mathrm{NO}_{3}^{-}\right]$suggest DOC and $\mathrm{P}$ share a common source, indicated by $\delta^{13} \mathrm{C}_{\mathrm{DOC}}$ to be dominantly of allochthonous origin. However DOC and $\mathrm{NO}_{3}^{-}$do not share a common source.

In tracing source, particularly in a site subject to disturbance, ${ }^{14} \mathrm{C}_{\mathrm{DOC}}$ may reveal if $\mathrm{C}$ export is from older, deeper, terrestrial stores. Unfortunately, we do not have ${ }^{14} \mathrm{C}_{\mathrm{DOC}}$ for Whitelee, or the Glen Dye sites with nutrient data. However, stream ${ }^{14} \mathrm{C}_{\text {DOC }}$ from Brocky (Glen Dye), sampled twice in 1998, was dominated by young carbon (Palmer et al., 2001), similar to DOC in the larger catchment post a hydrological event (Table 1). DOC from other peat drainage streams under non-baseflow conditions also is 'modern' (Evans et al., 2007; Billett et al., 2007), with a similar age range between low and high flow samples as between Brocky sampled in 1998 (Palmer et al., 2001) and its receiving stream under high flow in 2004 (Table 1). DOC exported from C-rich landscapes often appears younger than the soil $\mathrm{C}$, much of it comprising $\mathrm{C}$ assimilated since 1950s (Evans et al., 2007). Thus whilst we do not have ${ }^{14} \mathrm{C}_{\mathrm{DOC}}$ of the samples which were analysed for nutrients, the similarity of ${ }^{14} \mathrm{C}_{\mathrm{DOC}}$ from different $\mathrm{UK}$ peatland streams sampled over considerable temporal and spatial scales offers a more generic interpretation: although translocation of DOC within peatlands can yield young DOM in pores of older (deeper) peats (Chasar et al., 2000), the DOM pool exported largely derives from younger and shallower peats.

Given this, and linear relationships between $\mathrm{P}$ and DOC export for all sites, we infer that the $\mathrm{P}$ and DOC are also from shallow soils. Consequently soil disturbance may change concentrations of carbon and nutrient export (as a larger surface area may be exposed). However, unless older layers which contain more recalcitrant $\mathrm{C}$ and have stoichiometri- cally higher $\mathrm{C}: \mathrm{P}$ (or $\mathrm{C}: \mathrm{N}$ ) are disturbed, there may not be much change in the quality of the DOM.

4.2 Is the impact of disturbance of the terrestrial carbon and nutrient stores detectable outwith the immediate area of disturbance?

If the difference in [DOC], $[\mathrm{POC}]$ and $[\mathrm{P}, \mathrm{N}]$ in the run-off waters from $\mathrm{N}$ - and $\mathrm{S}$-catchments is due to differences in catchment characteristics, then if all remained equal between catchments, the offset should also remain broadly equal with time. This is not what we observe. As hypothesised, the S-catchments show increased $\mathrm{C}$ and $\mathrm{P}$ loads. $\Delta$ [DOC] between $\mathrm{N}$ - and $\mathrm{S}$-catchments starts increasing around April 2007 (Fig. 3a); a similar response is observed in $\Delta$ [POC] from July 2007 (Fig. 3b). Additionally, although both Nand S-catchments periodically exhibit hypertrophic $\mathrm{P}$ status, the trend since June 2007 when S-draining now surpassed Ncatchments in [TP] (and [SRP], time series data not shown), is consistent with a projected steady increase in [TP]. We do not observe the same switch in relative nitrate export. The stoichiometry of the export waters suggests the DOM pool is more limited in $\mathrm{P}$ than $\mathrm{N}$, thus consumption of $\left[\mathrm{NO}_{3}^{-}\right]$ is unlikely to be the primary cause for lack of concomitant increase in $\left[\mathrm{NO}_{3}^{-}\right]$. The lack of change in $\left[\mathrm{NO}_{3}^{-}\right]$further supports an interpretation that the soil profiles disturbed by development and / or new flow pathways that promote the increase in $\mathrm{C}$ and $\mathrm{P}$ export, are less important to nitrate delivery.

Whilst the time series we present here are short, the change suggests changes in flow pathways, perhaps through decomposing organic mulches or soil horizons previously less accessible, such as would occur after deforestation/peat disturbance. These changes are detectable downstream of the zone of disturbance. The lag in impact on the receiving waters with respect to the Whitelee development may reflect continued disturbance propagating downstream with time as buffering capacity upstream decreases or simply greater hydrological connectivity with wetter conditions.

In Whitelee we have not sampled headwater drainage systems nor targeted event export, yet [DOC] is significantly higher than many other non-headwater UK drainage systems (e.g., Worrall et al., 2004; Evans et al., 2007; Baker et al., 2008). [DOC] in S-catchments is comparable to that observed in smaller headwater catchments intimately connected with the peat landscape (e.g., the Brocky data; Dawson et al., 2004; Worrall et al., 2006; Dawson and Smith, 2007), but not as high as [DOC] in drainage waters from Auchencorth Moss: mean of $38.6 \mathrm{mg} \mathrm{C/L}$ (Billett et al., 2004). Auchencorth is a $3.5 \mathrm{~km}^{2}$ lowland ombotrophic raised bog only $25 \mathrm{~km}$ ENE from Whitelee. The catchment is smaller than the Whitelee catchments and slope gradient is shallower, thus water residence time may be longer. Both these differences may result in higher $[\mathrm{C}]$ in drainage waters. Auchencorth is also subject to disturbance, with peat harvest in $8 \%$ of the 
catchment and the extent to which this influences [DOC] export is unknown (Billett et al., 2004).

4.3 Using export budgets to consider the sensitivity of carbon landscapes (sequestration and $\mathrm{CO}_{2}$ efflux) to disturbance

Enhanced DOC export due to disturbance may reflect reduced capacity of a landscape to sequester carbon. Thus, where combined hydrographic and concentration data exist, it is valuable to convert flux measurements to budgets to create a better understanding of landscape carbon balance. There is little data for catchments the size of Whitelee (see Dawson and Smith, 2007 for a summary); research in this area tends to focus on headwaters catchments or large river basins, and study few meso-scale basins. For similar sized catchments for which there is data, only Moorhouse in the Pennine Hills of northern England, with 90\% peat cover and considered to be an eroding peat catchment (where POC exports most carbon loss, Evans et al., 2006) exports more carbon than the Whitelee sites. [DOC] can increase with \% peat coverage (e.g., Kortelainen et al., 2006), and thus the smaller OC export from Whitelee may reflect proportionally less peat in the catchment. This interpretation is further supported by the difference in $\mathrm{C}$ export between $\mathrm{N}$ and $\mathrm{S}$ draining catchments, and /or less erosion than Moorhouse.

Given the extent of UK peatland habitat, little data exists on $\mathrm{C}$ sequestration rates. That which does shows a range of approx 5-50 $\mathrm{g} \mathrm{C} \mathrm{m}^{-2} \mathrm{yr}^{-1}$ (e.g., Dawson and Smith, 2007), but with median values of closer to $25 \mathrm{~g} \mathrm{C} \mathrm{m}^{-2} \mathrm{yr}^{-1}$ (Hargreaves et al., 2003). ${ }^{210} \mathrm{~Pb}$ dating of three cores within peatland just outside the Whitelee development suggests $\mathrm{C}$ sequestration rates of $18.7 \mathrm{~g} \mathrm{C} \mathrm{m}^{-2} \mathrm{yr}^{-1}$ (MacKenzie pers. comm.), close to the median estimate for UK peatland. If this is representative of the Whitelee site, then aquatic export alone (11.7-25.5 $\mathrm{g} \mathrm{C} \mathrm{m}^{-2} \mathrm{yr}^{-1}$ is lost to the receiving waters) approaches suggested sequestration rates. If gaseous emissions and aquatic inorganic carbon export are included (the latter requires differentiation of $\mathrm{C}$ derived from organic matter respiration and export from minerogenic sources, Waldron et al., 2007), the budget for aquatic losses becomes larger. Further, our estimates of $\mathrm{C}$ loss are constructed from budgets that only latterly suggest an increase in OC export from disturbance. The projected impact of increased disturbance is to increase OC (and possibly inorganic carbon) export. In an undisturbed landscape, aquatic export represents one component of primary production that is not sequestered; in a disturbed landscape, aquatic loss may increase (e.g., as with Whitelee through enhanced POC export) and carbon sequestration rates may decrease. Ultimately if the disturbance if sufficiently large such sites may no longer act as a net carbon sink. Considered from the perspective of preserving a terrestrial carbon store, whether catchments have the capacity to buffer disturbance should be assessed.
Average annual TP export for Whitelee catchments $\left(28.8 \pm 5.5 \mathrm{~kg} \mathrm{P} \mathrm{km}^{-2} \mathrm{yr}^{-1}\right)$ is approximately six times higher than Finnish catchments (Kortelainen et al., 2006); Whitelee DOC export is almost three times higher than the Finnish catchments. If all DOC is converted to $\mathrm{CO}_{2}$ the flux estimate ranges from $6.7-18.9 \mathrm{~g} \mathrm{~cm}^{-2} \mathrm{yr}^{-1}$ across the catchments. This is larger than $\mathrm{CO}_{2}$ efflux measured directly by at Auchencorth Moss, $4.6 \mathrm{~g} \mathrm{C} \mathrm{m}^{-2} \mathrm{yr}^{-1}$ (Billett et al., 2007) or the estimated average of $4.1 \mathrm{~g} \mathrm{C} \mathrm{cm}^{-2} \mathrm{yr}^{-1}$ for the rivers of England and Wales (Worrall et al., 2007), but smaller than the measured efflux of $35.8 \mathrm{~g} \mathrm{~cm}^{-2} \mathrm{yr}^{-1}$ from rivers in the NE European tundra (measured only during the ice free period) considered to have come from the respiration of organic matter and free $\mathrm{CO}_{2}$ leached from the catchment (Heikkinen et al., 2004). It is likely that our estimate for potential $\mathrm{CO}_{2}$ efflux based on stoichiometric excess is greater than that effluxed from the system as not all DOC will be respired prior to export from the catchment. However, DOC is considerably in excess of $\mathrm{P}$, such that even if only a proportion of the DOC is processed, the system will likely be net heterotrophic and a source of atmospheric $\mathrm{CO}_{2}$. From our improved understanding of the relationship between DOC and nutrient export (Fig. 5) further increases in [DOC] are unlikely to be accompanied by sufficient $\mathrm{P}$ (or $\mathrm{N}$ ) to change the heterotrophic state of the drainage waters.

\section{Conclusions}

The systematic interaction of $\mathrm{C}$ export with other ecologically important elements such as $\mathrm{N}$ and $\mathrm{P}$ observed here, suggests that the terrestrial carbon cycle can be linked stoichiometrically to the atmospheric carbon cycle through aquatic biogeochemical cycling. Characterisation of the carbon and nutrient budgets is useful as it allows the rate at which carbon is being exported from terrestrial reservoirs to be quantified, and the link between terrestrial export of DOC to the atmospheric carbon cycle to be explored through assessing the potential for respiration. Future aquatic $\mathrm{CO}_{2}$ efflux studies may wish to incorporate a stoichiometric perspective to deepen the resolution such an approach can offer, with greatest interpretative power offered by linked DOC-nutrient-aquatic respiration studies. Our knowledge of the capacity for smaller catchments to emit $\mathrm{CO}_{2}$ is poor (Cole et al., 2007) and thus the simple estimates we provide here have value in, for example, identifying the most sensitive sites to study. However, as $\mathrm{CO}_{2}$ efflux from respired DOC can be influenced by lability of the organic material (Lovdal et al., 2007), the concentration and form of key nutrients (Lennon and Pfaff, 2005), and to what extent these are recycled (Rubin and Leff, 2007), greater advances will be made with a more detailed approach.

Whitelee is being developed for windpower and our study suggests disturbance impact is detectable at the larger scale. The consequence of changing nutrient stoichiometry of receiving waters on riverine carbon efflux is an aspect that does not appear in environmental impact statements to be 
given consideration. This is due to paucity of data rather than knowledge that such changes may not be of biogeochemical significance. The preliminary data we present here revealing temporal and spatial changes in stoichiometry of receiving waters, and that of an undisturbed system for comparison, contributes to the data framework required to develop such understanding and thus assess the impact on stoichiometry of receiving waters.

As the political importance of carbon geomorphology gathers momentum, flux estimates should be more prevalent in assessments of impact development on terrestrial carbon stores. At the scoping stage for renewable energy developments long-term monitoring is often required e.g., ecological surveys spanning one year. We suggest that future EIS should incorporate estimates of $\mathrm{C}$ sequestration and predevelopment losses prior to planning decisions. However, prior to using that knowledge in a decision-making capacity to offer guidance upon the viability of development on terrestrial carbon stores, we have an important question to address: Is it better to disturb a landscape where net balance approaches carbon loss, or it is better to disturb a site that has a high capacity to sequester carbon as here the buffering capacity of the site to disturbance will be greater, and the site may continue to sequester carbon? Answering this is not possible without more data on the natural variation in carbon fluxes and sequestration rates of terrestrial carbon stores, and the impact of disturbance.

Acknowledgements. SW was funded by a Natural Environment Research Council Advanced Fellowship, NER/J/S/2001/00793; ${ }^{14} \mathrm{C}$ analyses were funded by RCL allocation 1131.0405. Isotopic and stoichiometric analyses were undertaken at the Scottish Universities Environmental Research Centre (SUERC), which is funded by NERC and a consortium of Scottish Universities. We are grateful to Drumtee Farm, Polnoon House, Woodland Enterprise and the Fasque Estate for access to field sites, and to the Scottish Environment Protection Agency for discharge data. The following people are thanked: Chris Gallacher and Alison seton for contribution to nutrient data production; Kate Heal for comments on drafts of this manuscript and checking flux calculations; Helen Murray for collating POC data; Gus MacKenzie for calculations of carbon sequestration; Marian Scott for statistical advice; Jason Newton and Rona McGill at SUERC for support with mass spectrometry. Juuls Limpens and two anonymous referees are thanked for constructive criticism which considerably improved this manuscript.

Edited by: T. J. Battin

\section{References}

Baker, A., Cumberland, S., and Hudson, N.: Dissolved and total organic and inorganic carbon in some british rivers, Area, 40, 117-127, doi:10.1111/j.1475-4762.2007.00780.x, 2008.

Billett, M., Garnett, M., and Harvey, F.: UK peatland streams release old carbon dioxide to the atmosphere and young dissolved organic carbon to rivers, Geophys. Res. Lett., 34, 1-6, doi:10.1029/2007GL031797, 2007.
Billett, M. F., Palmer, S. M., Hope, D., Deacon, C., StoretonWest, R., Hargreaves, K. J., Flechard, C., and Fowler, D.: Linking land-atmosphere-stream carbon fluxes in a lowland peatland system, Global Biogeochem. Cy., 18, GB1024, doi:10.1029/2003GB002058, 2004.

Boutton, T. W., Wong, W. W., Hachey, D. L. , Lee, L, S., Cabrera, M. P., and Klein, P. D.: Comparison of quartz and pyrex tubes for combustion of organic samples for stable carbon isotope analysis, Anal. Chem., 55, 1832-1833, 1983.

Chasar, L. S., Chanton, J. P., Glaser, P. H., Siegel, D. I., and Rivers, J. S.: Radiocarbon and stable carbon isotopic evidence for transport and transformation of dissolved organic carbon, dissolved inorganic carbon and $\mathrm{CH}_{4}$ in a Minnesota peatland, Global Biogeochem. Cy., 14, 1095-1108, 2000.

Clesceri, L. S.: Standard methods for the examination of water and wastewater. Prepared and published jointly by American Public Health Association, American Water Works Association, Water Environment Federation, edited by: Clesceri, L. S., Greenberg, A. E., Eaton, A. D.], published Washington, Am. Pub. Health Ass., 20th edition, 1998.

Cole, J. J., Prairie, Y. T., Caraco, N. F., McDowell, W. H., Tranvik, L. J., Striegl, R. G., Duarte, C. M., Kortelainen, P., Downing, J. A., Middelburg, J. J., and Melack, J.: Plumbing the global carbon cycle: Integrating inland waters into the terrestrial carbon budget, Ecosystems, 10, 171-184, 2007.

CRE Energy: Whitelee windfarm environmental statement, Chapters 4 and 5, 14-36, 2002.

Cross, W. F., Benstead, J. P., Frost, P. C., and Thomas, S. A.: Ecological stoichiometry in freshwater benthic systems: Recent progress and perspectives, Fresh. Biol., 2005, 1895-1912, 2005.

Cummins, T. and Farrell, E. P.: Biogeochemical impacts of clearfelling and reforestation on blanket peatland streams I. phosphorus, For. Ecol. Manage., 180, 545-555, 2003.

Dawson, J. J. C., Bakewell, C., and Billett, M. F.: Is in-stream processing an important control on spatial changes in carbon fluxes in headwater catchments?, Sci. Tot. Env., 265, 153-167, 2001.

Dawson, J. J. C., Billett, M. F., Hope, D., Palmer, S. M., and Deacon, C. M.: Sources and sinks of aquatic carbon in a peatland stream continuum, Biogeochemistry, 70, 71-92, 2004.

Dawson, J. J. C. and Smith, P.: Carbon losses from soil and its consequences for land-use management, Sci. Total Environ., 382, 165-190, 2007.

Dodds, W. K.: Eutrophication and trophic state in rivers and streams, Limnol. Oceanogr., 51, 671-680, 2006.

Evans, C. D., Freeman, C., Monteith, D. T., Reynolds, B., and Fenner, N.: Climate change - terrestrial export of organic carbon reply, Nature, 415, 862-862, 2002.

Evans, C. D., Freeman, C., Cork, L. G., Thomas, D. N., Reynolds, B., Billett, M. F., Garnett, M. H., and Norris, D.: Evidence against recent climate-induced destabilisation of soil carbon from ${ }^{14} \mathrm{C}$ analysis of riverine dissolved organic matter, Geophys. Res. Lett., 34, LO7407, doi:10.1029/2007GL029431, 2007.

Evans, M., Warburton J., and Yang J., Eroding blanket peat catchments: Global and local implications of upland organic sediment budgets, Geomorphology, 79, 45-57, 2006.

Forestry Commission: Forests and water guidelines, Stationery Office Books, 36 pp., 1993.

Grieve, I. C.: Dissolved organic-carbon dynamics in 2 streams draining forested catchments at Loch Ard, Scotland, Hydr. Proc., 
8, 457-464, 1994.

Hargreaves, K. J., Milne, R., and Cannell, M. G. R.: Carbon balance of afforested peatland in Scotland, Forestry, 76, 299-317, 2003.

He, Z. Q., Ohno, T., Cade-Menun, B. J., Erich, M. S., and Honeycutt, C. W.: Spectral and chemical characterization of phosphates associated with humic substances, Soil Sci. Soc. Am. J., 70, 1741-1751, 2006.

Heikkinen, J. E. P., Virtanen, T., Huttunen, J. T., Elsakov, V., and Martikainen, P. J.: Carbon balance in east european tundra, Global Biogeochem. Cy., 18, GB1023, doi:10.1029/2003GB002054, 2004.

Hope, D., Palmer, S. M., Billett, M. F., and Dawson, J. J. C.: Variations in dissolved $\mathrm{CO}_{2}$ and $\mathrm{CH}_{4}$ in a first-order stream and catchment: An investigation of soil-stream linkages, Hydr. Proc., 18, 3225-3275, 2004.

Holden, J.: Piping and woody plants in peatlands: Cause or effect? Water Res. Res., 41, W06009, 2005.

Jordan, P., Arnschedit, A., McGrogan, H., and McCormick, S.: Characterising phosphorus transfers in rural catchments using a continuous bank-side analyser, Hydrol. Earth Sys. Sci., 11, 372381, 2007.

Kalbitz, K. and Geyer, S.: Different effects of peat degradation on dissolved organic carbon and nitrogen, Org. Geochem., 33, 319326, 2002.

Kortelainen, P., Mattsson, T., Finer, L., Ahtiainen, M., Saukkonen, S., and Sallantaus, T.: Controls on the export of C, N, P and Fe from undisturbed boreal catchments, Finland, Aqu. Sci., 68, 453-468, 2006.

Lennon, J. T.: Experimental evidence that terrestrial carbon subsidies increase $\mathrm{CO}_{2}$ flux from lake ecosystems, Oecologia, 138, 584-591, 2004.

Lennon, J. T., and Pfaff, L. E.: Source and supply of terrestrial organic matter affects aquatic microbial metabolism, Aqu. Microb. Ecol., 39, 107-119, 2005.

Levin, I. and Kromer, B.: The tropospheric ${ }^{14} \mathrm{CO}_{2}$ level in midlatitudes of the northern hemisphere (1959-2003). Radiocarbon, 46, 1261-1272, 2004.

Lovdal, T., Tanaka, T., and Thingstad, T. F.: Algal-bacterial competition for phosphorus from dissolved DNA, ATP, and orthophosphate in a mesocosm experiment, Limn. Ocean, 52, 1407-1419, 2007.

MAFF: The analysis of agricultural Materials, HMSO 3rd edition, Method 56, Organic matter in soil, 172-174, 1986.

Monteith, D. T., Stoddard, J. L., Evans, C. D., de Wit, H. A., Forsius, M., Hogasen, T., Wilander, A., Skjelkvale, B. L., Jeffries, D. S., Vuorenmaa, J., Keller, B., Kopacek, J., and Vesely, J.: Dissolved organic carbon trends resulting from changes in atmospheric deposition chemistry, Nature, 450, 537-540, 2007.

Neal, C.: The water quality functioning of the upper river Severn, Plynlimon, mid-Wales: Issues of monitoring, process understanding and forestry, Hydrol. Earth Sys. Sci., 8, 521-532, 2004.

Neal, C., Reynolds, B., Neal, M., Wickham, H., Hill, L., and Williams, B.: The impact of conifer harvesting on stream water quality: The Afon Harfen, mid-Wales, Hydrol. Earth Sys. Sci., 8, 503-520, 2004a.

Neal, C., Reynolds, B., Neal, M., Wickham, H., Hill, L., and Williams, B.: The water quality of streams draining a plantation forest on gley soils: The Nant Tanllwyth, Plynlimon mid-Wales,
Hydrol. Earth Sys. Sci., 8, 485-502, 2004b.

Osburn, C. L., Morris, D. P., Thorn, K. A., and Moller, R. E.: Chemical and optical changes in freshwater dissolved organic matter exposed to solar radiation, Biogeochem., 54, 251-278, 2001.

Palmer, S. M., Hope, D., Billett, M. F., Dawson, J. J. C., and Bryant, C. L.: Sources of organic and inorganic carbon in headwater streams: Evidence from carbon isotope studies, Biogeochem., 52, 321-338, 2001.

Rivers, J. S., Siegel, D. I., Chasar, L. S., Chanton, J. P., Glaser, P. H., Roulet, N. T., and McKenzie, J. M.: A stochastic appraisal of the annual carbon budget of a large circumboreal peatland, rapid river watershed, northern Minnesota, Global Biogeochem. Cyc., 12, 715-727, 1998.

Ross, M.: Can DOC export in peatland river catchment be described by the RCC?, B.Sc., Geographical and Earth Sciences, University of Glasgow, Glasgow, 35 pp., 2008.

Roulet, N. and Moore, T. R.: Browning the waters, Nature, 444, 283-284, 2006.

Rubin, M. A. and Leff, L. G.: Nutrients and other abiotic factors affecting bacterial communities in an Ohio river (USA), Micr. Ecol., 54, 374-383, 2007.

Smart, R. P., Cresser, M. S., Calver, L. J., Clark, M., and Chapman, P. J.: A novel modelling approach for spatial and temporal variations in nitrate concentrations in an $\mathrm{N}$-impacted UK small upland river basin, Env. Poll., 136, 63-70, 2005.

Slota, P. J., Jull, A. J. T., Linick, T. W., and Toolin, L. J.: Preparation of small samples for ${ }^{14} \mathrm{C}$ accelerator targets by catalytic reduction of CO, Radiocarbon, 29, 303-306, 1987.

Stuiver, M. and Polach, H. A.: Discussion: Reporting of ${ }^{14} \mathrm{C}$ data, Radiocarbon, 19, 355-363, 1977.

Tipping, E., Smith, E. J., Bryant, C. L., and Adamson, J. K.: The organic carbon dynamics of a moorland catchment in NW England, Biogeochem., 84, 171-189, 2007.

Thompson, D. B. A.; Gordon, J. E., Horsfield, D.: Montane landscapes in Scotland: are these natural artefacts or complex relicts?, in: Earth Science and the Natural Heritage, edited by: Gordon, J. E. and Leys, K. F., Stationary Office, London, 105-119, 2001.

Waddington, J. M. and Roulet, N. T.: Carbon balance of a boreal patterned peatland, Global Change Biol., 6, 87-97, 2000.

Waldron, S., Scott, E. M., and Soulsby, C.: Stable isotope analysis reveals lower-order river dissolved inorganic carbon pools are highly dynamic, Env. Sci. Tech., 41, 6156-6162, 10.1021/es0706089, 2007.

Worrall, F., Reed, M., Warburton, J., and Burt, T. P.: Carbon budget for a British upland peat catchment, Sci. Tot. Env., 312, 133-146, 2003.

Worrall, F., Harriman, R., Evans, C. D., Watts, C. D., Adamson, J., Neal, C., Tipping, E., Burt, T., Grieve, I., Monteith, D., Naden, P. S., Nisbet, T., Reynolds, B., and Stevens, P.: Trends in dissolved organic carbon in UK rivers and lakes, Biogeochem., 70, 369402, 2004.

Worrall, F., Burt, T. P., and Adamson, J.: The rate of and controls upon DOC loss in a peat catchment, J. Hydr., 321, 311-325, 2006.

Worrall, F., Guilbert, T., and Besien T.: The flux of carbon from rivers: the case for flux from England and Wales, Biogeochem., 86, 63-75, 2007. 